\title{
DOKUMENTY TAJNEJ POLICJI FRANCUSKIEJ (SÛRETÉ NATIONALE) I ARCHIWUM PAULA DESJARDINSA W ZASOBIE ARCHIWUM IPN - PRZEGLĄD ARCHIWALIÓW
}

\author{
Aneta Nisiobęcka iD http://orcid.org/0000-0003-4292-4482 \\ Archiwum Instytutu Pamięci Narodowej
}

\begin{abstract}
DOCUMENTS OF THE FRENCH SECRET POLICE (SÛRETÉ NATIONALE) AND THE ARCHIVES OF PAUL DESJARDINS IN THE ARCHIVES OF THE INSTITUE OF NATIONAL REMEMBRANCE REVIEW OF THE ARCHIVES
\end{abstract}

The article focuses on presenting French archival documents from the collection of the Commander of the Security Police and Security Service in France (der Befehlshaber der Sicherheitspolizei und des Sicherheitsdienstes in Frankreich) in the archives of the Institute of National Remembrance (IPN). In 1982 the collection was transferred by the Central Archives of the Ministry of Interior to the Central Archives Commission for the Investigation of Crimes against the Polish Nation, and then in 2000 it was transferred to the IPN Archives. Twenty-eight archival units from this collection concern the synarchist movement, its functioning in the 1930s and during the Vichy regime in France, as well as the famous intellectual meetings in Pontigny (Les Décades de Pontigny) organized by Professor Paul Desjardins.

Keywords: French Secret Police, Paul Desjardins, ten-day meetings in Pontigne, synarchist movement.

Słowa kluczowe: Sûreté National, Paul Desjardins, spotkania dekadowe w Pontigny, ruch synarchistyczny.

Zbiór dokumentów Dowódcy Policji Bezpieczeństwa i Służby Bezpieczeństwa we Francji (Der Befelshaber der Sicherheitspolizei und des Sicherheitsdienst in Frankreich, nr GK 660)ํㅡㄹ został przekazany przez Centralne Archiwum MSW do archiwum

\footnotetext{
${ }^{1}$ Właściwa nazwa powinna brzmieć: Der Befehlshaber der Sicherheitspolizei und des SD (Sicherheitsdienst) im Bereich des Militärbefehlhabers in Frankreich.
}

Adres do korespondencji: aneta.nisiobecka@interia.pl 
Głównej Komisji Badania Zbrodni przeciwko Narodowi Polskiemu w 1982 roku. Następnie na mocy art. 68 ustawy o Instytucie Pamięci Narodowej z 18 grudnia 1998 roku przeszedł do zasobu Archiwum IPN.

Po II wojnie światowej dokumenty te znalazły się w posiadaniu Departamentu VII (wywiadu) Ministerstwa Bezpieczeństwa Publicznego (MBP). W Archiwum IPN trudno dziś ustalić, w jaki sposób dokumenty Dowódcy Policji Bezpieczeństwa i Służby Bezpieczeństwa ( $\mathrm{SiPo}$ ) znalazły się w posiadaniu wywiadu MBP. Wystarczy dodać, że w naukowej literaturze archiwalnej w Polsce na temat rabunku i przejmowania archiwaliów francuskich przez Niemców pisano bardzo mało ${ }^{2}$. Dlatego też w oparciu o poczynione ustalenia można przypuszczać, że dokumenty zostały na przełomie 1943 i 1944 roku wywiezione z Francji na teren Śląska, Czech i do Berlina $^{3}$. Te dokumenty, które przewieziono na Śląsk, w 1945 roku po zmianie granic Polski znalazły się być może już bezpośrednio w polskim posiadaniu.

Zespół ten liczący w całości 259 j.a. zawiera, między innymi dokumenty administracyjno-finansowe oraz doniesienia agenturalne SiPo, materiały dotyczące Kościoła katolickiego we Francji, francuskiego ruchu oporu, francuskich kolaborantów, agentów gestapo, policji i partii faszystowskich działających na terenie Francji w czasie II wojny światowej. Po 1948 roku Departament VII MBP przekazał dokumenty do archiwum jako nieprzydatne operacyjnie.

W 67 jednostkach archiwalnych zbioru GK 660 znajdują się dokumenty i korespondencja w sprawie francuskich pracowników zatrudnionych w placówkach SiPo na obszarze Dowódcy Wojskowego we Francji, zestawienia wypłaconych wynagrodzeń osobom zatrudnionym w Sicherheitspolizei-SD-Kommando (między innymi w Angers, Orleanie, Nancy, Poitiers, Rouen, Rennes, Bordeaux, Dijon, Saint-Quentin), dokumentację finansową Zahlstelle Paris urzędu Dowódcy Policji Bezpieczeństwa i Służby Bezpieczeństwa we Francji, meldunki placówek SiPo w Poitiers i Nancy oraz meldunki sytuacyjne SiPo na obszarze Dowódcy Wojskowego we Francji i doniesienia agenta ps. „T-200”.

Jednak najwięcej dokumentów tego zespołu (100 jednostek archiwalnych) dotyczy działalności Kościoła oraz organizacji katolickich we Francji w latach 30. XX wieku oraz w okresie II wojny światowej. Są to przede wszystkim sprawozdania oraz doniesienia agenturalne sporządzone w języku francuskim na temat episkopatu i duchownych. Niektóre z nich zostały przetłumaczone na język niemiecki.

Z charakterystycznych materiałów należy wyróżnić akta śledztwa przeciwko Alfredowi Gauthier (trzy jednostki archiwalne) aresztowanemu 18 listopada 1940 roku i przetrzymywanemu w więzieniu Karola III w Nancy. Jako jedyny z 33 oskarżonych o pomoc w przekroczeniu linii demarkacyjnej Francuzom pragnącym dołączyć do Komitetu Wolnej Francji w trwającym procesie od 13 do 15 stycznia 1941 roku

${ }^{2}$ Zob. m.in. P. Libera, Restytucja archiwaliów francuskich z Archiwum Specjalnego w Moskwie, „Archeion” 2006, t. CIX, s. 131-157; P. Kennedy Grimsted, Dwukrotnie zrabowane i nadal z dala od ojczyzny. Losy trzech bibliotek stowiańskich przejętych przez nazistów w Paryżu, „Archeion” 2003, t. CVI, s. 47-84.

${ }^{3}$ P. Libera, op. cit., s. 136-142. 
został skazany na karę śmierci przez rozstrzelanie $e^{4}$ Należy również wskazać trzy jednostki archiwalne pochodzące $\mathrm{z}$ archiwum Force française de l'intérieur (FFI) oraz Franc-tireurs et partisans français (FTPF) dotyczące, między innymi likwidacji kolaborantów oraz agentów gestapo w okresie okupacji 5 .

Ponadto w zespole (od jednej do kilku jednostek archiwalnych) znajdują się między innymi raporty placówki Wydziału IV RSHA w Paryżu, zarządzenia i korespondencja w sprawie przesiedlenia osób z Alzacji i Lotaryngii, zarządzenia w sprawie volksdeutchów zamieszkujących na terenie Francji, materiały z aresztowań komunistów francuskich w departamentach Charante-Maritime, Charante i Gironde, pokwitowania z konfiskat mienia przeprowadzanych u Żydów zamieszkałych we Francji, dokumenty dotyczące partii francuskich - Parti populaire français (PPF) i Rassemblement national populaire (RNP) - kolaborujących z hitlerowskimi Niemcami, organizacji francuskich działających przed 1940 rokiem, takich jak: Comité national de l'Organisation française de la Jeunesse, Association pour les États généraux de la Jeunesse, spraw kolonialnych Francji (w tym akta Maurice'a Mouteta, ministra kolonii francuskich w latach 1936-1938 w rządzie Leona Bluma i Camille'a Chautemps) oraz sesje Ligii Narodów z lat 1930-1936. Odnośnie do spraw polskich warta odnotowania jest jednostka archiwalna dotycząca funkcjonowania w czasie wojny Centre d'Accueil pour les Réfugiés polonais (wedle dokumentów założonego w Paryżu przez markizę A. de Bonnières).

Zbiór GK 660 zawiera przede wszystkim dokumenty zgromadzone i wytworzone przez SiPo. Nie ulega wątpliwości, że ten scharakteryzowany syntetycznie materiał źródłowy zasługuje na oddzielne naukowe omówienia.

W zespole oprócz wspomnianych wyżej dokumentów znajdują się również materiały archiwalne Dyrekcji Generalnej Bezpieczeństwa Narodowego Francji w Paryżu - Sûreté Nationale - przejęte przez SiPo w czasie II wojny światowej (28 jednostek archiwalnych) na temat ruchu synarchistycznego i jego funkcjonowania w latach 30 . XX wieku oraz w okresie reżimu Vichy we Francji (kojarzonego z masonerią, o czym dalej), a także słynnych spotkań intelektualnych w Pontigny (Les Décades de Pontigny) organizowanych przez profesora Paula Desjardinsa w latach 1910-1914, 1922-1939. Fakt, że materiały pochodzą z archiwum Sûreté Nationale, spowodawał, iż zostały one wybrane na temat tego artykułu.

Dokumenty zawierają notatki, sprawozdania, korespondencje, raporty na temat spraw kościoła oraz ich kopie. W większości są to dokumenty w języku francuskim. Ponadto akta zawierają korespondencję w języku angielskim. Często dokumenty są opatrzone streszczeniami i komentarzami policji niemieckiej. Należy jednocześnie

\footnotetext{
${ }^{4}$ http://www.museedelaresistanceenligne.org/media10347-Alfred-Gauthier [dostęp: 24 XI 2020 r.].

${ }_{5}^{5}$ Dokumenty pochodzące z archiwum FFI i TPF w 1953 r. zostały przekazane przez Departament VII MBP Centralnego Archiwum, ponieważ nie miały „żadnej wartości operacyjnej”. IPN GK 660/249, Kommandeur der SiPo und SD in Paris, Wniosek o przekazanie do archiwum Departamentu VII MBP teczki pod kryptonimem „Archiwum FFI i FTPF” referenta Sekcji III Wydziału I Departamentu VII MBP ppor. M. Lipińskiego, Warszawa, XI 1953 r., k. 1. Na dole pisma wpisano odręcznie: „Przesłać do Centralnego Archiwum".
} 
podkreślić, że tylko w trzech jednostkach archiwalnych znajdujemy dokumenty z prywatnego archiwum Paula Desjardinsa.

Ruch synarchistyczny, jego historia, działalność i rola w polityce francuskiej w latach 30. i 40. ubiegłego wieku oraz historia francuskiej myśli intelektualnej w okresie międzywojennym to problematyka podejmowana przez francuskich historyków i tamtejszych znawców tematu ${ }^{6}$. Z tego szczególnego powodu archiwaliom francuskim znajdującym się w zasobie archiwalnym IPN, które gromadzi materiały dotyczące zbrodni nazistowskich i komunistycznych oraz aparatu bezpieczeństwa obu reżimów, warto poświęcić uwagę.

Wyjaśnić również należy, że w zasobie Archiwum IPN bardziej obszerna jest dokumentacja dotycząca kongresów Centre d'étude des problèmes humains (CEPH) w Pontigny (korespondencja i stenogramy kongresów), których inicjatorem i prowadzącym w latach 1935-1939 był Jean Coutrot, niż dokumentacja letnich dekad w Pontigny. Ta ostatnia jest bardzo szczątkowa.

Można przypuszczać, że prywatna korespondencja Jeana Coutrota z Paulem Desjardinsem znalazła się w posiadaniu Sûreté Nationale po dokonaniu przeszukania w domu Jeana Coutrota, oskarżonego w 1941 roku o przynależność do spisku przeciwko państwu francuskiemu. Według informacji znajdujących się na opisie teczki o sygn. GK 660/103 mieszkanie żony Paula Desjardinsa - Charlotte Desjardins - zostało przeszukane przez SiPo w nocy z 21 na 22 sierpnia 1941 roku, która zarekwirowała listy: Ramona Fernandeza do Paula Desjardinsa i Liliane Chomette do Paula Desjardinsa. Policja niemiecka prawdopodobnie przeszukiwała mieszkania osób, które miały powiązania z Jeanem Coutrotem. Wszystkie dokumenty, które przejęła SiPo po Sûreté Nationale, lub te, które znalazły się w posiadaniu policji niemieckiej, są opatrzone thumaczeniami na język niemiecki, w tym prywatna korespondencja Ramona Fernandeza.

Wyjaśnić należy, że artykuł ten nie pretenduje do naukowej analizy zawartości materiałów archiwalnych, lecz ma na celu dokonanie przeglądu dokumentacji francuskiej, tak znacząco różniącej się tematycznie od materiałów przechowywanych w zasobach IPN. Artykuł podzielono na trzy części. Pierwsza jest poświęcona dokumentacji pochodzącej z prywatnego archiwum Paula Desjardinsa, druga dotyczy organizacji kongresów CEPH, w ostatniej przedstawiono dokumentację dotyczącą ruchu synarchistycznego we Francjī .

${ }^{6}$ Zob. m.in. F. Chaubet, Paul Desjardins et les Décades de Pontigny, Villeneuve-d'Ascq 2000; idem, Les Décades de Pontigny (1910-1939), „Vingtième Siècle. Revue d'histoire” 1998, vol. 57, no 1, s. 36-44; idem, L'Union pour l'action morale et spiritualisme républicain (1892-1905), „Mil neuf cent. Revue d'histoire intellectuelle" 1998, no 17, s. 67-89; O. Dard, La synarchie ou le mythe du complot permanent, Paris 2012; idem, Jean Coutrot: de l'ingénieur au prophète, Besançon 1999.

${ }^{7} \mathrm{~W}$ polskiej literaturze historycznej brakuje wyczerpującej monografii na temat intelektualistów francuskich w okresie międzywojennym. To samo odnosi się do polskiej literatury historycznej dotyczącej przedstawicieli partii politycznych i głównych polityków w państwie francuskim okresu międzywojennego i II wojny światowej, którzy byli związani z ruchem masońskim. Literatura dostępna w Polsce traktująca o historii Francji do 1945 r. ogranicza się do wyjaśnienia i przedstawienia najważniejszych wydarzeń politycznych w historii państwa francuskiego. O historii Francji okresu II wojny światowej pisał m.in. J. Eisler, Od monarchizmu do faszyzmu. Koncepcje polityczno-społeczne prawicy francuskiej 


\section{SPOTKANIA DEKADOWE W PONTIGNY (LES ENTRETIENS D’ÉTÉ)}

Pomysłodawcą słynnych spotkań w Pontigny był Paul Desjardins (1859-1940), profesor i dziennikarz francuski, zwolennik obozu intelektualnej lewicy, piszący między innymi do „La Revue Bleue” i „Le Figaro”. Był uczniem profesora filozofii Jules’a Lagneau. Wraz z nim oraz kilkoma innymi osobami założyli w 1893 roku Unię na rzecz Akcji Moralnej (L'Union pour l'Action Morale), zamienioną następnie na Unię na rzecz Prawdy (l'Union pour la Vérité). Ruch ten propagował zasady etyczne niezwiązane z religią 8 .

Po rozdziale Kościoła od państwa we Francji w 1905 roku9 Paul Desjardins, obrońca kapitana Alfreda Dreyfusa, odkupił opactwo cystersów z XIII wieku w Pontigny w departamencie Yonne w Burgundii. Od 1910 roku organizował tam intelektualne spotkania, które odbywały się do 1914 roku, a następnie zostały wznowione w 1922 roku. Ostatnie spotkanie dekadowe odbyło się latem 1939 roku. Dekady Pontigny miały charakter spotkań intelektualnych. Przez 10 dni osobistości francuskiego życia politycznego, kulturalnego i intelektualnego dyskutowały na temat literatury, filozofii, religii i polityki. Spotkania odbywały się w gronie 30-50 osób ${ }^{10}$. Każdego dnia jedna $\mathrm{z}$ osób przedstawiała wystąpienie na takie tematy jak: prawa człowieka, edukacja i praca, miejsce religii w życiu Francji, myśl filozoficzna Francji i Europy. W spotkaniach uczestniczyli między innymi: André Gide, Roger Martin du Gard, André Maurois, Jacques Rivière, François Mauriac, Antoine de Saint-Exupéry. Uczestnikami byli również Ramon Fernandez i jego żona Liliane Chomette, o których więcej poniżej.

1918-1940, Warszawa 1987; idem, Kolaboracja we Francji 1940-1944, Warszawa 1989; idem, Philippe Pétain (1856-1951), Warszawa-Wrocław-Gdańsk, 1991; T. Janasz, Państwo francuskie 1940-1944. Ideologia, organizacja, prawa, Warszawa-Wrocław, 1977; eadem, Państwo francuskie wobec kwestii żydowskiej 1940-1944, Warszawa-Wrocław 1968. Zob. także: R. Aron, Histoire de Vichy, t. 1, 2, avec la collaboration G. Elgey, Paris 1976; H.R. Lottman, Lewy brzeg. Od frontu ludowego do zimnej wojny, tłum. J. Giszczak, Warszawa 1997.

${ }^{8}$ Więcej zob. F. Chaubet, L'Union pour l'action morale..., s. 67-89; J.E. Zamojski, „Décades de Pontigny” - elitaryzm intelektualistów czy humanistyczna utopia?, „Dzieje Najnowsze” 1996, nr 1, s. $247-260$.

${ }^{9}$ Do rozdziału Kościoła od państwa we Francji doszło po wybuchu słynnej afery Dreyfusa. Alfred Dreyfus, ur. 1859 r., kapitan sztabu generalnego pochodzenia żydowskiego został skazany w 1894 r. na dożywocie za szpiegostwo na rzecz Niemiec na podstawie spreparowanych dowodów. Sprawa Dreyfusa podzieliła opinię publiczną Francji na „dreyfusistów” i ,antydreyfusistów”. Podział ten okazał się bardzo brzemienny w skutki dla życia politycznego kraju. Francuska prawica została zepchnięta na margines, a po objęciu rządów przez Blok Lewicy wprowadzono w życie uregulowania dotyczące rozdzielenia Kościoła od państwa. Ustawę o rozdziale Kościoła od państwa referowana w 1905 r. w Izbie Deputowanych przez Aristide'a Brianda pozostawiała mienie Kościołowi i powierzała sprawy materialne organizacjom do spraw kultu. J. Baszkiewicz, Historia Francji, wyd. II poprawione i uzupełnione, Wrocław-Warszawa-Kraków-Gdańsk 1978, s. 621-625,629-630. G. Lefebre, Ch.H. Potas, M. B aumont, Historia Francji, t. 2: Od 1774 do czasów wspótczesnych, thum. M. Derenicz, Warszawa 1969, s. 433.

${ }^{10}$ F. Chaubet, Les décades de Pontigny..., s. 36. 
Spotkania dekadowe w Pontigny przerwały hegemonię filozofów skupionych wokół czasopisma „Nouvelle Revue Française” ${ }^{11}$. Były one czymś nowym w środowisku intelektualnym Francji. Pozwoliły na spotkania profesorów i uczniów reprezentujących trzy renomowane szkoły: Collège de France, Sorbonę i l'École normale supérieure de Saint-Cloud ${ }^{12}$. Uczniowie i studenci mieli prawo głosu na równi z akademickimi autorytetami i pierwszoplanowymi intelektualistami. Spędzali tam długie wieczory w swobodnej atmosferze w towarzystwie znakomitości, do których, według Herberta Lottmana, nie mogliby dotrzeć w innych okolicznościach. Spotkania dekadowe były zamknięte: wchodziło się tam wyłącznie za zaproszeniem i podobnież tylko nielicznym udało się bez niego tam dostać ${ }^{13}$.

Zanim jednak Paul Desjardins zainicjował spotkania w Pontigny, w latach 1892 1910 współtworzył debaty pod patronatem Unii na rzecz Akcji Moralnej, które odbywały się w starej okazałej kamienicy, w małej niskiej salce, na lewym brzegu Sekwany przy ul. Visconti 21 w Paryżu. Od 1904 roku Unia na rzecz Akcji Moralnej stała się Unią na rzecz Prawdy. W czasie tych debat dyskutowano często na tematy kontrowersyjne, co uczyniło z nich jeden z głównych ośrodków kulturalnych „lewego brzegu" Paryża.

W broszurze z 1911 roku, która znajduje się w zasobie Archiwum IPN, Desjardins ma nadzieję, że dekady osiągną rozmiar międzynarodowy. Zaznaczył jednocześnie, że spotkania te nie mają charakteru oficjalnych kongresów, a ich głównym celem jest poszukiwanie „wolności ducha”. Według ich fundatora miały za zadanie nieść: „pomoc swoim członkom w kształtowaniu opinii i oceny". Spotkania paryskie uznawano już za niewystarczające i członkowie Unii na rzecz Prawdy poszukiwali innej formy spotkań $^{14}$.

Po śmierci Paula Desjardinsa w 1940 roku, jego córka Anne Heurgon-Desjardins sprzedała opactwo ojcom od św. Edmunda (les pères de Saint Edme) ${ }^{15}$ i odnowiła zamek w Cerisy-la-Salle w departamencie Manche - dawną posiadłość matki. Kontynuowała spotkania intelektualne w latach 1947-1952 w opactwie Royaumont w departamencie Val-d'Oise, a w 1952 roku ufundowała Międzynarodowe Centrum

${ }^{11}$ Ibidem, s. 37.

${ }^{12}$ Ibidem, s. 37-38.

${ }_{13}$ H.R. Lottman, op. cit., s. 68-69.

${ }^{14}$ IPN GK 660/128, Kommandeur der SiPo und SD in Paris, Entretiens d'été de l'Abbaye de Pontigny, deuxième année, août-septembre 1911, k. 327 (poszyt 2, s. 10-15).

${ }^{15}$ Inaczej nazywani również edmuntystami (la communauté de Saint-Edmond, Oblats du Sacré-Cœur de Jésus et du Cour Immaculé de Marie). Kleryckie zgromadzenie zakonne założone w 1843 r. w Pontigny pod patronatem Edmunda z Abingdon. Ojcem założycielem zgromadzenia był J.B. Muard (1809-1854). W 1843 r. zainicjował on powstanie grupy ojców zakonnych wspomagających duchowieństwo diecezjalne (prêtres auxiliaires). J.P. Boyer (1813-1892) zreorganizował grupę w formalną wspólnotę opartą na regule benedyktyńskiej. Celem tej wspólnoty miało być działalność duszpasterska. W 1876 r. reguła wspólnoty została zatwierdzona na prawie diecezjalnym, a w 1916 r. na prawie papieskim. Od pontyfikatu papieża Leona XIII edmuntyści zaczęli prowadzić własne zakłady nauczania. W wyniku antykościelnych reform we Francji opuścili kraj w 1901 r. i założyli domy zakonne w Anglii, Stanach Zjednoczonych oraz Kanadzie. Do Francji powrócili w 1926 r. i objęli duszpasterstwo w Pontigny. W 1964 r. podjęli działalność misyjną i założyli placówkę w Wenezueli. 
Kulturalne w Cerisy-la-Salle i Stowarzyszenie przyjaciół Pontigny-Cerisy. Przyjmowała tam wielu filozofów i literatów takich jak: Raymond Aron, Martin Heidegger, Francis Ponge, Raymond Queneau, Eugène Ionesco oraz Witold Gombrowicz, który latem 1964 roku był gościem w opactwie Royaumont. Dzieło Paula Desjardinsa i jego córki Anne Heurgon Desjardins po jej samobójczej śmierci w 1977 roku kontynuuje Edith Heurgon.

Wśród zachowanych dokumentów w zasobie Archiwum IPN znajduje się korespondencja osobistości życia intelektualnego Francji do Paula Desjardinsa i Jeana Coutrota (korespondencja do Paula Desjardinsa jest bardzo szczątkowa) informująca o uczestnictwie w spotkaniach letnich i konferencjach organizowanych przez CEPH, dokładny harmonogram wystąpień poszczególnych osób, listy uczestników w spotkaniach, notatki, biuletyny informacyjne na temat spotkań w Pontigny wydawane przez Paula Desjardinsa, poszczególne numery czasopism i codziennych gazet, protokoły wystąpień i dyskusji.

W zbiorze GK 660 zachowała się w dobrym stanie dokumentacja dotycząca dekad organizowanych w Pontigny z lat 1910-1938. Fundacja letnich spotkań w Pontigny założona przez Paula Desjardinsa drukowała programy konferencji i spotkań i wydawała je własnym nakładem. W wydanym programie z okazji 25 . rocznicy spotkań znajdujemy takie tematy trzech dyskusji: spotkanie sierpniowe od 1 do 11 sierpnia 1935 roku - Wiktor Hugo znawca „rzeczy boskich”, drugie spotkanie sierpniowe od 12 do 22 sierpnia 1935 roku - Granice urojone $i$ rzeczywiste, trzecie spotkanie sierpniowe od 23 sierpnia do 2 września 1935 roku - Ascetyzm i jego twórcza siła ${ }^{16}$. Ponadto zachowały się programy spotkań z 1911 roku, 1928 roku, 1930 roku, 1933 roku. W czasie tych spotkań myśliciele intelektualnej Francji dyskutowali na takie tematy jak: Czas i człowiek, Pojęcie rytmu w sztuce, Pojęcie wolnego czasu. W 1926 roku rozmawiano na tematy: Reforma państwa, w 1927 roku - Konieczne wolności, w 1929 roku-Mieszczaństwo, w 1931 roku-Kolonizacja. Pod koniec lat 30. dyskutowano o zagrożeniu Europy przez dwa totalitaryzmy: nacjonalizm niemiecki i komunizm ${ }^{17}$. W sierpniu 1937 roku miało miejsce drugie w tym roku dekadowe spotkanie w Pontigny, poświęcone filozofii ${ }^{18}$.

W zasobie zachowały się odręczne notatki i zapiski z trzeciego spotkania dekadowego z września 1924 roku. Notatki te mają charakter sprawozdania sporządzonego z kolejnych wypowiedzi rozmówców ${ }^{19}$. Na tym spotkaniu dyskutowano między innymi o polityce równowagi, sytuacji politycznej w Europie, pojęciu zwycięstwa.

${ }^{16}$ IPN GK 660/128, Kommandeur der SiPo und SD in Paris, Programme de trois conversations dirigés chacune de dix jours, Abbaye de Pontigny, Été 1935, k. 277-282.

${ }_{17}$ Wszystkie te spotkania były podzielone na trzy dekady i odbywały się w VIII. Ibidem, k. 327, Le temps et l'homme (poszyt nr 6); Du Rythme comme principe du délectation et d'expression dans la technique de divers arts, et comme donné naturelle (poszyt nr 3); Le loisir chez tous les travailleurs en général (poszyt nr 4); F. Chaubet, Les décades de Pontigny..., s. 42-43.

${ }^{18}$ IPN GK 660/128, Kommandeur der Sipo und SD in Paris, $2^{\text {ème }}$ décade 1937 du mardi 24 août au vendredi le 3 septembre de l'unité de philosophie, k. 33.

${ }^{19}$ Ibidem, s. 327 (poszyt nr 8). 
W programie dwóch dekad sierpniowych w 1937 roku znalazły się tematy: Postawa Ligi Narodów do aktualnej sytuacji w Europie, Nowoczesne techniki populizmu, Dramatyzm, Reżyseria, Kreowanie symboli ${ }^{20}$.

Zachowała się korespondencja z lat 1937-1938 między Paulem Desjardinsem i Jeanem Coutrotem (o jego aktywności w dalszej części artykułu) w sprawie organizowania kongresów w opactwie Pontigny oraz członków Centre d'études des problèmes humains (CEPH) informujących o swoim uczestnictwie w kongresach ${ }^{21}$. Nie jest wykluczone, że Jean Coutrot mógł uczestniczyć w spotkaniach dekadowych Paula Desjardinsa. Nie ulega wątpliwości, że letnie spotkania w Pontigny miały ogromne znaczenie dla francuskiej myśli filozoficznej. Spotkania stały się instytucją kulturalną zarówno francuską, jak i europejską. François Chaubet uważa, że broniły one wartości uniwersalnych niszczonych przez totalitaryzmy lat 30 . ubiegłego wie$\mathrm{ku}$, idei powołania i działalności Ligii Narodów oraz idei demokracji. Dyskutowano o problemach społeczno-politycznych, o konieczności reform. Były to wymiany myśli i poglądów na poziomie europejskim, dotyczące problemów uniwersalnych ${ }^{22}$. Do szczególnej atmosfery tych historycznych spotkań przyczynił się niewątpliwie klimat francuskiej prowincji, tak inny od paryskich salonów.

Broszury oraz nikła korespondencja na temat dekad Pontigny znajdują się w teczce o sygnaturze akt GK 660/128. Pierwsze kilka stron to korespondencja Paula Desjardinsa i Charlotte Desjardins z lat 1936-1938. Ostatnia strona teczki to koperta (strona 327), która zawiera osiem broszur: Są to broszury ze spotkań letnich w Pontigny z lat 1911, 1930 (tu w dwóch egzemplarzach), 1933 i 1928 roku, broszura CEPH „La genèse des mythes” („Geneza mitów”) z 1938 roku, broszura po szwedzku o Paulu Desjardinsie i dekadach Pontigny (brak daty) oraz ręcznie spisane sprawozdanie z trzeciej dekady letniej w Pontigny z września 1928 roku. W teczce akt o sygn. GK 660/222 znajdują się listy Eugenio d'Ors i dyrektora l'Organisation internationale du Travail Alberta Thomasa do Paula Desjardinsa z lat 1926 i $1930^{23}$. W tej samej teczce znajdują się dwa prywatne listy Waltera Horna do Paula Desjardinsa w języku niemieckim z 1929 roku $^{24}$.

Z prywatnego archiwum Paula Desjardinsa pochodzą listy Ramona Fernandeza i jego żony Liliane Chomette do Paula Desjardinsa z lat 1925-193225. W aktach o sygnaturze GK 660/103 znajduje się razem sześć listów Ramona Fernandeza i Liliane Chomette do Paula Desjardinsa. Dwa z nich zostały napisane na maszynie, cztery listy Liliane Chomette do Paula Desjardinsa z 1932 roku - odręcznie. Zachowało

${ }^{20}$ Ibidem, Pontigny, Été 1937, k. 4-5.

${ }^{21}$ Ibidem [Korespondencja Jeana Coutrota i członków CEPH, 1937-1938], k. 40-74, 79-189.

${ }^{22}$ F. Chaubet, Les décades de Pontigny..., s. 44.

23. IPN GK 660/222, Kommandeur der SiPo und SD in Paris, [Korespondencja Eugenio d'Ors i Alberta Thomasa, 1926, 1931 r.], k. 22-26, 31-33.

${ }^{24}$ Zapewne chodzi o Waltera Horna, uznanego badacza architektury średniowiecznej. W zachowanej korespondencji pisze on o przyjeździe do Pontigny studentki historii sztuki, która przygotowywała pracę poświęconą wpływom artystów rzeźbiarzy z Chartres w XIII-wiecznej sztuce niemieckiej. Ibidem, k. $40-44$.

${ }^{25}$ IPN GK 660/103, Kommandeur der SiPo in SD in Paris, [Listy Ramona Fernandeza i Liliane z lat 1925-1932 zerekwirowane w domu Charlotte Desjardins przez SiPo w dn. 21-22 VIII 1941 r.], k. 1-12. 
się ponadto zaproszenie ojca Liliane Chomette Pierre'a Chomette'a z okazji jej zaślubin z Ramonem Fernandezem 1 grudnia 1926 roku w Paryżu. Według informacji zapisanych na okładce teczki listy zostały zarekwirowane w domu Charlotte Desjardins w czasie przeszukania przez SiPo 21 sierpnia 1941 roku. Z tego też powodu zostały one przetłumaczone na język niemiecki.

Ramon i Liliane uczestniczyli w dekadach w Pontigny. Liliane była jedną z ulubionych uczennic profesora Paula Desjardinsa, a Ramon Fernandez w okresie międzywojennym publikował na łamach NRF. W czasie wojny kolaborował z rządem Vichy. Twierdzil, że bez pomocy Niemiec w Europie może zapanować komunizm. Zmarł 2 sierpnia 1944 roku z powodu zawału serca ${ }^{26}$.

Hipotetycznie można założyć również, że SiPo przeszukało mieszkanie Paula i Charlotte Desjardinsów nie tylko ze względu na powiązania z Jeanem Coutrotem, ale być może również ze względu na Ramona Fernandeza. Ramon Fernandez przed wojną był znany ze swoich lewicowych poglądów, w czasie wojny zmienił postawę polityczną i poparł rząd reżimu Vichy. Na uwagę zasługuje tutaj również data przeszukania mieszkania państwa Desjardinsów - 21 sierpnia 1941 roku. W tym dniu ukazał się artykuł w tygodniku „L'Appel” o samobójczej śmierci Jeana Coutrota i jego powiązaniach z synarchią. Nie ulega wątpliwości, że policja niemiecka poszukiwała i sprawdzała wszystkie ślady mogące świadczyć o powiązaniach z ruchem synarchistycznym.

\section{KONGRESY CENTRE D'ÉTUDE DES PROBLÈMES HUMAINS (CEPH) W PONTIGNY ORGANIZOWANE PRZEZ JEANA COUTROTA}

Materiały znajdujące się w Archiwum IPN dotyczą kongresów CEPH z lat 19361939 i zawierają korespondencję jego fundatora - Jeana Coutrota z Paulem Desjardinsem oraz jego korespondencję z uczestnikami kongresów z lat 1936-1939.

Kim był Jean Coutrot? Urodził się w 1895 roku. Był z zawodu inżynierem i ekonomistą, pionierem stowarzyszeń oraz organizacji pracowników i pracodawców. Współtworzył grupę X-Crise, Centrum Politechniczne Studiów Ekonomicznych (Centre politechnicien d'études économiques - CPEE), a następnie wspomniane już CEPH. W gabinecie ministra ekonomii Charles'a Spinasse'a w latach 30. XX wieku był wiceprzewodniczącym Centrum Krajowego Naukowej Organizacji Pracy. W czasie II wojny światowej został zmarginalizowany przez reżim Vichy. Popełnił samobójstwo 19 maja 1941 roku, przyczyną była pogłębiająca się u niego depresja ${ }^{27}$.

${ }^{26}$ Więcej czyt. m.in. D. Fernandez, Ramon, Paris 2009; P. Ory, Les Collaborateurs 1940-1945, Paris 1976.

${ }^{27} \mathrm{O}$ jego śmierci pisano m.in. w artykule Une association mystérieuse de polytechniciens, d'inspecteurs des finances et de financiers s'est constituée depuis dix ans en France pour prendre le pouvoir..., „L'Appel”, 21 VIII 1941 r., s. 1, 3. Patrz w: IPN GK 660/134, Kommandeur der Sipo und SD in Paris, k. 72/4-72/5. 
Jego śmierć odbiła się echem we Francji, głównie w kontekście politycznym. Nazwisko Coutrota pojawiało się już w okresie międzywojennym, jako jednego z członków „spisku synarchistycznego" przeciwko państwu francuskiemu ${ }^{28}$.

W dossier o sygn. GK 660/128 zachowały się protokoły wystąpień i dyskusji rannych i popołudniowych konferencji CEPH z 1, 2 i 3 października 1938 roku. Dyskutowano między innymi o nowym układzie sił w Europie, zagrożeniu ciążącym na Czechosłowacji oraz o pojęciu pokoju ${ }^{29}$. W dniach 14-18 maja 1937 roku w opactwie Pontigny kongres organizowało CEPH, którego jednym z twórców był Jean Coutrot. Podczas majowego kongresu rozmawiano o problemach jednostki we współczesnym świecie ${ }^{30}$. Na podstawie programu wiadomo, że profesorowie w swoich referatach poruszali kwestie między innymi związane z problemem kolonizacji, ludzkimi postawami. Następna konferencja została zorganizowana w październiku $1937 \mathrm{roku}^{31}$. Z dokumentów wynika, że CEPH organizowało je do $1939 \mathrm{roku}^{32}$.

Październikowa sesja CEPH z 1938 roku była podzielona na trzy spotkania. W programie przewidziano dyskusję na tematy, takie jak: metodologia pracy w naukach socjologicznych, struktury administracyjne państwa i kształcenie kadry urzędniczej, nowe tendencje w ekonomii politycznej, aktualny stan gospodarki rosyjskiej ${ }^{33}$.

W teczce o sygn. GK 660/222, liczącej 274 kolejno ponumerowane karty, zachowała się korespondencja dotycząca organizacji kongresów CEPH, programy konferencji oraz listy osób, które uczestniczyły lub miały uczestniczyć w kongresach. Korespondencja lat 1936-1939 jest adresowana do pomysłodawcy kongresów Jeana Coutrota. Osoby, które korespondowały z Coutrotem, były związane głównie z naukami ekonomicznymi lub finansami ${ }^{34}$.

Korespondencja dotycząca kongresów CEPH znajduje się również w sygnaturze akt GK 660/128, z której wynika, że Paul Desjardins był członkiem Rady CEPH ${ }^{35}$. Całość dokumentów sklasyfikowanych pod tą sygnaturą, oprócz kilku pierwszych stron dokumentacji o intelektualnych spotkaniach letnich w Pontigny, dotyczy organizacji kongresów CEPH.

${ }^{28}$ IPN GK 660/249, Kommandeur der SiPo und SD in Paris, Mouvements politiques, source: Balin, objet: Le Mouvement synarchique d'empire, origine: S.T, valeur: sûre, k. 26.

${ }^{29}$ IPN GK 660/128, Kommandeur der SiPo und SD in Paris, Entretiens de Pontigny, premier entretien, samedi, le $1^{\text {er }}$ octobre [1938], réunion de l'après-midi, k. 209-276.

${ }^{30}$ Ibidem, Liste des personnalités ayant participé effectivement aux débats de Pontigny, b.d., k. 37; ibidem, Réunion du Centre d'étude des problèmes humains à l'Abbaye de Pontigny du 14 au 18 mai 1937, k. 36-39.

${ }^{31}$ Ibidem, Lettre de Jean Coutrot, Paris, septembre 1937, k. 40-41.

32 IPN GK 660/222, Kommandeur der SiPo und SD in Paris, [Korespondencja Centre d'études des problèmes humains, 1939], k. 231-274.

${ }^{33}$ IPN GK 660/128, Kommandeur der SiPo und SD in Paris, $5^{\mathrm{e}}$ session plenière du Centre d'études des problèmes humains, Pontigny, les $1^{\text {er }}, 2,3$ octobre 1938, k. 108-109.

${ }^{34}$ IPN GK 660/222, Kommandeur der SiPo und SD in Paris, [Korespondencja Jeana Coutrota za okres 1931-1939], k. 21-274.

${ }^{35}$ IPN GK 660/128, Kommandeur der SiPo und SD in Paris, Liste des membres conseillers du CEPH, b.d., k. 110. 


\section{DOKUMENTY DOTYCZACCE RUCHU SYNARCHISTYCZNEGO W ZASOBIE ARCHIWALNYM ARCHIWUM IPN}

Tajny raport i jego kopie na temat ruchu synarchistycznego we Francji zgromadzone zostały przez Sûreté Nationale i przejęte następnie przez SiPo w czasie II wojny światowej. Często dokumenty te są opatrzone komentarzami policji niemieckiej.

$Z$ analizy źródeł wynika, że Jean Coutrot był liderem ruchu synarchistycznego ${ }^{36}$. W dokumentach znajdujących się w zasobie Archiwum IPN jego postać przedstawia się jako głównego organizatora kongresów CEPH w Pontigny. Korespondował on z Paulem Desjardinsem w sprawie organizacji kongresów w maju i październiku każdego roku. Ponadto zachowała się również korespondencja uczestników tych kongresów, w której potwierdzali swój udział w kongresach, oraz programy i stenogramy kongresów.

Czym był we Francji ruch synarchistyczny? Synarchia jest to dążenie do zaprowadzenia ustroju porządkującego wszystkie sfery bytu społecznego (religijną, polityczną, gospodarczą i kulturalną) według zasad hierarchii, ładu i autoryteu. Pojęcie synarchii rozwinął francuski okultysta Alexandre Saint-Yves d'Alveydre (18421909). Pojęcie to okazało się bardzo wpływowe w polityce europejskiej. D'Alveydre uważał, że synarchia miała być środkiem na szerzącą się wtedy anarchię. Wyjaśniał, że synarchiści powinni kontrolować najważniejsze instytucje społeczne, edukacyjne, prawne i ekonomiczne. Uważał, że synarchia powinna połączyć dwa bieguny życia narodowego: władzy (le pouvoir) i autorytetu (l'autorité). Autorytet powinien czuwać nad kulturą, sprawiedliwością i ekonomią, a władza - nad administracją, sprawami międzynarodowymi, finansami ${ }^{37}$.

Stowarzyszenie synarchistyczne (Ordre Martiniste Synarchique) zostało założone przez Wiktora Blancharda w 1921 roku. Przynależność do niego w latach 40. $\mathrm{XX}$ wieku we Francji była równoznaczna z przynależnością do spisku przeciwko państwu Vichy ${ }^{38}$.

Z tym właśnie pojęciem synarchii łączona jest osoba Jeana Coutrota, który był twórcą grupy X-Crise utworzonej w 1930 roku. Wśród członków byli znani absolwenci Szkoły Politechnicznej. Na bazie tej grupy powstało CPEE, które zgromadziło wielu znanych osobistości życia finansowego Francji. Uważali oni, że jest możliwe utworzenie „trzeciej drogi” pomiędzy liberalnym kapitalizmem a komunizmem. Doktryna ta nazywana jest planizmem, a czołowym jej teoretykiem był członek X-Crise Marcel Déat, późniejszy założyciel Socjalistycznej Partii Francji, która demonstrowała swoje prohitlerowskie sympatie. Nie może więc dziwić obecność

${ }^{36}$ IPN GK 660/249, Kommandeur der SiPo und SD in Paris, Mouvements politiques, source: Balin, objet: Le Mouvement synarchique d'empire, origine: S.T, valeur: sûre, k. 26.

${ }^{37}$ Synarchia, oprac. J. Bartyzel w: Encyklopedia ,, biatych plam”, tom. XVII: St-Vo, Radom 2006, s. 38-40; IPN GK 660/140, Kommandeur der SiPo und SD in Paris; Synarchie, le 23 septembre 1941, k. 42-46; IPN GK 660/249, Kommandeur der SiPo und SD in Paris, Mouvements politiques, source: Balin, objet: Le Mouvement synarchique d'empire, origine: S.T, valeur: sûre, k. 26.

${ }^{38}$ Synarchizm, oprac. J. Bartyzel w: Encyklopedia ,biatych plam”..., s. 40-41. 
planistów w administracji reżimu Vichy. Ci najbardziej gorliwi byli skupieni wokół premiera Pierre'a Lavala. Przeciwni im byli tak zwani péteniści skupieni przy marszałku Francji Philippie Pétainie. Po zarekwirowaniu przez tajną policję francuską Paktu Synarchistycznego ${ }^{39}$ w maju 1941 roku doszło do konfliktu w obozie planistów. Déat oskarżył synarchistów o spiskowanie przeciwko rewolucji narodowej. Istnieją przypuszczenia, że powodem jego ataku mogło być finansowanie przez Bank Worms konkurującej partii Jeacques'a Doriota. Od tego też momentu w historiografii francuskiej, a także w ideologicznym znaczeniu termin synarchia oznaczał polityczną i ekonomiczną konspirację ${ }^{40}$.

Co więcej, ruch synarchistyczny w czasie II wojny światowej we Francji był traktowany jako stowarzyszenie masońskie. Henri du Moulin de Labarthète, dyrektor gabinetu Pétaina powiedział, że marszałek nie znosił masonerii i że w przeciwieństwie do Żydów, którzy nie są odpowiedzialni za swoje pochodzenie, przynależność do masonerii była wyborem.

Po zajęciu Francji przez wojska niemieckie rozpoczęto rozpracowywanie wolnomularstwa francuskiego (np. loży Grand Orient de France). Władze niemieckie zajęły ich lokale, gdyż uważały, że wolnomularze pomagają w ukrywaniu Żydów. Ta polityka spotkała się ze zrozumieniem ze strony rządu Vichy. Ustawa z 13 sierpnia 1940 roku zabraniała zebrań i tajnych stowarzyszeń, a art. 5 tej ustawy zakazywał funkcjonariuszom i urzędnikom państwa francuskiego przynależności do tajnych organizacji - było to traktowane jako zagrożenie dla odbudowy państwa. Sześć dni później dekretem zlikwidowano działalność Grand Orient de France i La Grande Loge de France, a masonerię francuską oskarżano o antypaństwowy spisek. Podejrzenia objęły także członków Synarchie d'empire. Należy zaznaczyć, że masoni chociaż byli podejrzewani przez państwo francuskie - nie byli prześladowani przez reżim Vichy jak Żydzi. Sam Laval starał się poskramiać gorliwość swoich ludzi $\mathrm{W}$ tropieniu masonerii ${ }^{41}$.

W maju 1941 roku Philippe Pétain znalazł na swoim biurku tajną notę na temat tajnego stowarzyszenia „Synarchia”. Została ona napisana przez Henriego Martina, byłego przywódcy tajnej organizacji politycznej o charakterze skrajnie prawicowym pod nazwą La Cagoule, utworzonej w 1935 roku $^{42}$. Notę oparto na dokumencie pod nazwą „Pakt synarchistyczny na rzecz panowania francuskiego” (Pacte synarchiste révolutionnaire pour l'empire français ${ }^{43}$, który podobnież odnaleziono $\mathrm{w}$ domu

${ }^{39}$ Tekst paktu czyt. m.in. IPN GK 660/130, Kommandeur der SiPo und SD in Paris, M.S.E. Les treize points fondamentaux et 597 propositions du pacte synarchique revolutionnaire pour l'empire français, k. $1-117$.

40 Synarchizm, oprac. J. Bartyze1, s. 40-41.

${ }^{41}$ J.P. Azéma, O. Wieviorka, Vichy 1940-1944, Paris 2004, s. 154-156. Według Jerzego Eislera komuniści, Żydzi i masoni byli głównymi wrogami niemieckich okupantów, a tym samym ekipy Pétaina. J. Eisler, Od monarchizmu do faszyzmu..., s. 170.

42 J. Eisler, Od monarchizmu do faszyzmu..., s. 107. „La Cagoule” postawiło sobie cel obalenie rządów Frontu Ludowego. A.M. Jackow ska, Sowiety na ławie oskarżonych. Polskie uczestnictwo w propagandowej zimnej wojnie we Francji w latach 1947-1952, Warszawa 2018, s. 31.

${ }^{43}$ IPN GK 660/130, Kommandeur der SiPo und SD in Paris, M.S.E. Les treize points fondamentaux et 597 propositions de pacte synarchiste revolutionnaire pour l'empire français, k. 1-117. Fragmenty 
Jeana Coutrota. Pakt zawierał 598 propozycji przedstawionych w 13 podstawowych zasadach, które miały doprowadzić do wprowadzenia nowego systemu politycznego.

Nota Martina definiuje wyraźnie charakter tajnego stowarzyszenia jako spisku. Martin sugerował w nim, że stowarzyszenie synarchistyczne było odpowiedzialne za usunięcie 13 grudnia 1940 roku z rządu ministra spraw zagranicznych Pierre'a Lavala. Na wieczornym posiedzeniu Rady Ministrów 13 grudnia 1940 roku Philippe Pétain zażądał dymisji na piśmie od wszystkich członków rządu. Ostatecznie Pétain przyjął dymisję ministra oświaty Georges'a Riperta i wiceprzewodniczącego Rady Ministrów i ministra spraw zagranicznych Pierre'a Lavala. Uważa się, że winnymi „przewrotu pałacowego" byli minister finansów Yves Bouthillier i minister spraw wewnętrznych Marcel Peyrouton. Podejrzenia o udział w „przewrocie” padały również w kierunku François Darlana, od lutego 1941 roku wicepremiera, ministra spraw wewnętrznych, spraw zagranicznych, informacji marynarki i wojny. W „pałacowym zamachu stanu" aresztowano także Marcela Déata. Petain chciał Lavala odsunąć z rządu ze względu na różnice w kwestii stosunku do Niemiec i Wielkiej Brytanii ${ }^{44}$.

Według noty Martina członkami tego synarchistycznego związku mieli być inżynierowie szkół politechnicznych i finansiści spotykający się w lokalu banku Worms. Celem tej grupy było obalenie idei rewolucji narodowej tworzonej przez Philippe'a Pétaina oraz kierowanie państwem przez grupy finansistów i ochronę interesów żydowskich i angielskich. W lipcu 1941 roku powstał raport, nazywany „,raportem Chavina", przedstawiający stowarzyszenie synarchistyczne jako spisek międzynarodowego kapitalizmu, którego zadaniem było „opanować gospodarczo inne kraje i kontrolować je przez pewne grupy powiązane z jednym głównym bankiem" ${ }^{45}$, co zresztą miał potwierdzać wcześniejszy raport Martina. Po powstaniu ruchu synarchistycznego (Mouvement synarchique d'empire MSE - MSE) raport z lipca potwierdzał, że organizacja La Cagoule była zbrojnym ramieniem MSE. Nota z 31 lipca 1942 roku podaje, że MSE nie posiadała „grupy uderzeniowej”. Za taki oddział był uznawany La Légion Tricolore, którego niektórzy członkowie mogli stanąć w opozycji do rządu i samego Pierre'a Lavala ${ }^{46}$. Teksty tajnych raportów o ruchu synarchistycznym oraz jego kopie przechowywane są w zasobie archiwalnym Archiwum IPN ${ }^{47}$.

Francuska prasa związana z reżimem Vichy zarzucała organizacji synarchistycznej sabotowanie słynnych porozumień w Montoire i chęć porozumienia się z Wielką

i kopie tekstu paktu znajdują się jeszcze w IPN GK 660/133, Kommandeur der SiPo und SD in Paris, M.S.E. Les trois points fondamentaux et 597 propositions de pacte synarchiste revolutionnaire pour l'empire français, k. 21-44, 64-87 i IPN GK 660/144, Kommandeur der SiPo und SD in Paris, Rapport no 1 de l'informateur A, k. 2-133.

44 J. Eisler, Kolaboracja we Francji 1940-1944..., s. 143-144, 151-152.

${ }^{45}$ IPN GK 660/137, Kommandeur der Sipo und SD in Paris, Note, Paris, le 31 juillet 1942, k. 119.

${ }^{46}$ Ibidem.

${ }^{47}$ Teksty tajnych raportów znajdują się m.in. w IPN K 660/133, Kommandeur der Sipo und SD in Paris, [Raporty poufne o ruchu synarchistycznym], k. 13-239. Inny tekst raportu na temat działalności Mouvement synarchique d'empire (MSE) opatrzony komentarzami w języku niemieckim znajduje się w: IPN GK 660/131, Kommandeur der SiPo und SD in Paris, k. 74-119. Kopia raportu na temat MSE znajduje się również w: IPN GK 660/141, Kommandeur der SiPo und SD in Paris, k. 172-187; IPN GK 660/144, Kommandeur der SiPo und SD in Paris, Rapport no 1 de l'informateur A, k. 2-133. 
Brytanią i Stanami Zjednoczonymi ${ }^{48}$. Z kolei Marcel Déat, który obwiniał François Darlana (zastąpił Pierre-Etienne'a Flandina ${ }^{49}$ ) za odsunięcie od władzy Pierre'a Lavala, podał kilka nazwisk osób z gabinetu Darlana powiązanych z bankiem Worms ${ }^{50}$. Te osoby zastały w rządzie aż do powrotu Lavala do władzy w kwietniu 1942 roku Powiązania tych osób miały swój początek jeszcze w latach 30. ze wspomnianą wyżej grupą X-Crise, której członkami byli między innymi Jean Coutrot, Pierre Pucheu, Jules Moch, Louis Vallon.

Według niektórych historyków francuskich ruch synarchistyczny nie miał na celu obalenia idei rewolucji narodowej Pétaina. Reprezentował on interesy grup powiązanych z innymi niemieckimi organizacjami i dążył do bliższej współpracy z hitlerowskimi Niemcami.

$$
* * *
$$

W artykule scharakteryzowano zawartość materiałów zgromadzonych i wytworzonych przez Sûreté Nationale z zespołu Dowódcy Policji Bezpieczeństwa i Służby Bezpieczeństwa we Francji dotyczące intelektualnych spotkań w Pontigny i ruchu synarchistycznego. Nie ulega wątpliwości, że dokumenty przechowywane w Archiwum IPN są interesującym materiałem źródłoznawczym do badania historii spotkań intelektualnych, ruchu masońskiego we Francji w latach 20., 30. i 40. ubiegłego wieku, zarówno dla polskich, jak i francuskich historyków. Dzięki nim możliwe jest pogłębienie wiedzy na temat polityki reżimu Vichy.

\section{BIBLIOGRAFIA}

Archiwum Instytutu Pamięci Narodowej w Warszawie

Komandeur der Sipo und SD in Paris, IPN GK 660/103, 660/128, 660/130, 660/131, 660/133, 660/134, 660/137, 660/140, 660/141, 660/144, 660/222, 660/249

48 Spotkania odbyły się 22 i 24 X 1940 r. w wagonie na stacji kolejowej w Montoire między Pierre'em Lavalem a Adolfem Hiltlerem i Joachimem von Ribentroppem, a następnie między Pétainem i Hitlerem. Więcej o przebiegu rozmów zob. m.in. J. Eisler, Kolaboracja we Francji 1940-1944..., s. 127-138; J. Baszkiewicz, op. cit., s. 668.

49 Pierre-Etienne Flandin przejął ministerstwo spraw zagranicznych po odsunięciu Lavala z rządu 13 XII 1940 r. Od II 1941 r. resortem kierował François Darlan. J. Eisler, Kolaboracja we Francji $1940-1944 \ldots$, s. $145,157$.

${ }^{50}$ Według noty z 31 VII 1942 r. w organizacji synarchistycznej rozróżniano dwie grupy: pierwsza to grupa okultystyczna, natomiast druga o „charakterze ekonomicznym” miała swoje miejsce spotkań w lokalu banku Worms. IPN GK 660/137, Kommandeur der SiPo und SD in Paris, Note, Paris, le 31 juillet 1942, k. 119v. 


\section{Literatura}

Aron R., Histoire de Vichy, t. 1, 2, avec la collaboration G. Elgey, Paris 1976.

Azéma J.P., Wieviorka O., Vichy 1940-1944, Paris 2004.

Baszkiewicz J., Historia Francji, wyd. II poprawione i uzupełnione, Wrocław-WarszawaKraków-Gdańsk 1978.

Chaubet F., Les Décades de Pontigny (1910-1939), „Vingtième Siècle. Revue d'histoire” 1998, vol. 57, no 1, p. 36-44.

Chaubet F., Paul Desjardins et les Décades de Pontigny, Presses Universitaires du Septentrion, Villeneuve-d'Ascq 2000.

Chaubet F., L'Union pour l'action morale et spiritualisme républicain (1892-1905), „Mil neuf cent" 1998 , no 17 , p. 67-89.

Dard O., Jean Coutrot: de l'ingénieur au prophète, Besançon 1999.

Dard O., La synarchie ou le mythe du complot permanent, Paris 2012.

Eisler J., Kolaboracja we Francji 1940-1944, Warszawa 1989.

Eisler J., Od monarchizmu do faszyzmu. Koncepcje polityczno-społeczne prawicy francuskiej 1918-1940, Warszawa 1987.

Eisler J. Philippe Pétain (1856-1951), Warszawa-Wrocław-Gdańsk 1991.

Encyklopedia ,biatych plam”, tom. XVII: St-Vo, Radom 2006.

Fernandez D., Ramon, Paris 2009.

Jackowska A. M., Sowiety na ławie oskarżonych. Polskie uczestnictwo w propagandowej zimnej wojnie we Francji w latach 1947-1952, Warszawa 2018.

Janasz T., Państwo francuskie 1940-1944. Ideologia, organizacja, prawa, WarszawaWrocław 1977.

Janasz T., Państwo francuskie wobec kwestii żydowskiej 1940-1944, Warszawa-Wrocław 1968.

Kennedy Grimsted P., Dwukrotnie zrabowane i nadal z dala od ojczyzny. Losy trzech bibliotek słowiańskich przejętych przez nazistów w Paryżu, „Archeion” 2003, t. CVI, s. $47-84$.

Lefebre G., Potas Ch. H., Baumont M., Historia Francji, t. 2: Od 1774 do czasów wspótczesnych, tłum. M. Derenicz, Warszawa 1969.

Libera P., Restytucja archiwaliów francuskich z Archiwum Specjalnego w Moskwie, „Archeion" 2006, t. CIX, s. 131-157.

Lottman H. R., Lewy brzeg. Od frontu ludowego do zimnej wojny, tłum. J. Giszczak, Warszawa 1997.

Ory P., Les Collaborateurs 1940-1945, Paris 1976.

Zamoj ski J. E, „Décades de Pontigny”-elitaryzm intelektualistów czy humanistyczna utopia?, „Dzieje Najnowsze” 1996, nr 1, s. 247-260. 